\title{
Towards the development of a salinity impact category for South African environmental life-cycle assessments: Part 1 - A new impact category
}

\author{
Tony Leske and Chris Buckley* \\ Pollution Research Group, School of Chemical Engineering, University of Natal, Durban 4041, South Africa
}

\begin{abstract}
Environmental life-cycle assessments conducted in South Africa to date have made use of published equivalency (or characterisation) factors for characterising ecotoxicity effects. These factors are calculated using environmental fate and effect models, and generate equivalency factors that are not necessarily valid for South African conditions. Furthermore, current models do not adequately characterise the effects of common ions associated with salinity impacts. Salinisation of South African water resources is of strategic concern, and the need for life-cycle assessments to be able to incorporate salinity effects is apparent. There are sufficiently clear cause-effect relationships between the sources and impacts of salinity, and impacts are sufficiently different in nature from existing categories to warrant a separate salinity impact category. A conceptual method is proposed for creating a new salinity impact category for life-cycle assessment and for calculating salinity equivalency factors. The proposed method meets the international requirements for creating new impact categories and it is recommended that the method be developed further.
\end{abstract}

Keywords: environmental life-cycle assessment, salination

\section{Introduction}

The environmental life-cycle assessment (LCA) technique for evaluating the environmental impact of products from cradle to grave is not new. Environmental assessments of products were carried out as far back as the 1960s. From the end of the 1980s, however, interest in LCA has grown strongly, and the methodological development has reached the point where standardisation has occurred through organisations such as the International Organisation for Standardisation and SETAC (Wenzel et al., 1997).

Details of the LCA method are described elsewhere (Wenzel et al., 1997). Briefly; releases of all environmentally significant compounds to the environment from all stages of a product's lifecycle are inventoried (for example, in units of $\mathrm{kg}$ substance released per kg of product produced). During the next stage (classification /characterisation), each impact parameter of the inventory table is converted into a contribution to one or more environmental themes, or impact categories. This is done by multiplying the mass of compound released due to the life-cycle activity by equivalency factors (or characterisation factors) for the compound. Equivalency factors are calculated using characterisation models. In terms of the requirements of ISO 14042, the following impact categories and sub-categories are obligatory:

- Depletion of abiotic resources

- Effects of land use

- Increase in land competition

- Climate change

- Stratospheric ozone depletion

- Human toxicity

\footnotetext{
* To whom all correspondence should be addressed.

巡 +2731 260 2186; fax: +2731 260 1118; e-mail: buckley@nu.ac.za

Received 30 August 2002; accepted in revised form 19 May 2003.
}

- Eco-toxicity

- Fresh-water aquatic

- Marine

- Terrestrial

- Photo-oxidant formation

- Acidification

- Nutrification.

The following additional optional categories have been defined, and are not obligatory at this stage.

- Effects of land use

- Loss of life support

- Loss of biodiversity

- Toxicity

- Fresh-water sediment

- Marine sediment

- Radiation

- Depletion of biotic resources

- Desiccation

- Noise

- Waste heat

- Casualties.

\section{Characterisation}

Several characterisation models are available for estimating equivalency factors for each compound contributing to a specific impact category (See Table 1 for the models generally in use). Equivalency factors are generally estimated using environmental fate and exposure models, and are indicators of the probability of exposure and probability that the exposure leads to an effect (i.e. risk). The impact parameters (or release) for each compound and each compartment are multiplied by the respective equivalency factors and the results are added to give a total score for each impact category. 


\begin{tabular}{|c|c|c|c|c|c|}
\hline \multicolumn{6}{|c|}{$\begin{array}{l}\text { TABLE } 1 \\
\text { Characterisation models available for selected categories (Guinee, 2000) }\end{array}$} \\
\hline $\begin{array}{l}\text { Impact } \\
\text { category }\end{array}$ & LCI result & $\begin{array}{l}\text { Characterisation } \\
\text { model }\end{array}$ & $\begin{array}{l}\text { Category } \\
\text { indicator }\end{array}$ & $\begin{array}{l}\text { Characterisation } \\
\text { factor }\end{array}$ & $\begin{array}{l}\text { Indicator } \\
\text { result }\end{array}$ \\
\hline Abiotic depletion & $\begin{array}{l}\text { Extraction of minerals } \\
\text { and fossil fuels }\end{array}$ & $\begin{array}{l}\text { Concentration } \\
\text { reserves and rate of } \\
\text { de-accumulation } \\
\text { approach }\end{array}$ & Reserve depletion & $\begin{array}{l}\text { Abiotic depletion } \\
\text { factor (ADF) for each } \\
\text { extraction of minerals } \\
\text { and fossil fuels (kg } \\
\text { antimony equivalents } / \mathrm{kg} \\
\text { extraction) }\end{array}$ & $\begin{array}{l}\mathrm{kg} \text { of antimony } \\
\text { equivalents }\end{array}$ \\
\hline $\begin{array}{l}\text { Increase in land } \\
\text { competition }\end{array}$ & $\begin{array}{l}\mathrm{m}^{2} \text { per year of land } \\
\text { use }\end{array}$ & - & - & - & $\begin{array}{l}\mathrm{m}^{2} \text { per year of } \\
\text { land use }\end{array}$ \\
\hline Climate change & $\begin{array}{l}\text { Emissions of } \\
\text { greenhouse gases } \\
\text { to air }\end{array}$ & $\begin{array}{l}\text { Model as developed } \\
\text { by the International } \\
\text { Panel on Climate } \\
\text { Change (IPCC) } \\
\text { defining the global } \\
\text { warming potential } \\
\text { of different } \\
\text { greenhouse gases }\end{array}$ & $\begin{array}{l}\text { Infrared radiative } \\
\text { forcing }\left(\mathrm{W} / \mathrm{m}^{2}\right)\end{array}$ & $\begin{array}{l}\text { Global warming } \\
\text { potential } 100 \text { year time } \\
\text { horizon }(\mathrm{GWP} 100) \text { for } \\
\text { each greenhouse gas } \\
\text { emission to air }\left(\mathrm{kg} \mathrm{CO}_{2} /\right. \\
\mathrm{kg} \text { emission) }\end{array}$ & $\begin{array}{l}\mathrm{kg} \mathrm{CO}_{2} \text { equiva- } \\
\text { lents }\end{array}$ \\
\hline $\begin{array}{l}\text { Depletion of } \\
\text { stratospheric ozone }\end{array}$ & $\begin{array}{l}\text { Emission of ozone- } \\
\text { depleting gases to air }\end{array}$ & $\begin{array}{l}\text { Model as developed } \\
\text { by the World Meteo- } \\
\text { rological Organisation } \\
\text { (WMO) defining the } \\
\text { ozone depletion } \\
\text { potential of different } \\
\text { gases }\end{array}$ & $\begin{array}{l}\text { Stratospheric ozone } \\
\text { breakdown }\end{array}$ & $\begin{array}{l}\text { Ozone depletion } \\
\text { potential in the steady- } \\
\text { state emission of each } \\
\text { substance to air }\end{array}$ & $\begin{array}{l}\mathrm{kg} \mathrm{CFC}-11 \\
\text { emissions }\end{array}$ \\
\hline Human toxicity & $\begin{array}{l}\text { Emissions of toxic } \\
\text { substances to air, } \\
\text { water and soil }\end{array}$ & $\begin{array}{l}\text { USES fate and } \\
\text { exposure model } \\
\text { developed by RIVM }\end{array}$ & $\begin{array}{l}\text { Ratio of acceptable } \\
\text { to predicted daily } \\
\text { intake }\end{array}$ & $\begin{array}{l}\text { Human toxicity potential } \\
\text { (HTP) for each emission } \\
\text { to air, water and soil }\end{array}$ & $\begin{array}{l}\mathrm{kg} \text { 1,4-dichloro } \\
\text { benzene } \\
\text { equivalents }\end{array}$ \\
\hline Eco-toxicity & $\begin{array}{l}\text { Emissions of toxic } \\
\text { substances to air, } \\
\text { water and soil }\end{array}$ & $\begin{array}{l}\text { USES fate and } \\
\text { exposure model } \\
\text { developed by RIVM }\end{array}$ & $\begin{array}{l}\text { Ratio of Predicted } \\
\text { Environmental } \\
\text { Concentration (PEC) } \\
\text { to Predicted No } \\
\text { Effect Concentration } \\
\text { (PNEC) (for sub- } \\
\text { categories; fresh- } \\
\text { water aquatic, fresh- } \\
\text { water sediment, } \\
\text { marine, marine sedi- } \\
\text { ment and terrestrial) }\end{array}$ & $\begin{array}{l}\text { Eco-toxicity potentials } \\
\text { for each sub-category }\end{array}$ & $\begin{array}{l}\mathrm{kg} \text { 1,4-dichloro- } \\
\text { benzene } \\
\text { equivalents }\end{array}$ \\
\hline $\begin{array}{l}\text { Photo-oxidant } \\
\text { formation }\end{array}$ & $\begin{array}{l}\text { Emissions of } \\
\text { substances (VOC, } \\
\mathrm{CO} \text { ) to air }\end{array}$ & $\begin{array}{l}\text { UNECE Trajectory } \\
\text { Model }\end{array}$ & $\begin{array}{l}\text { Tropospheric } \\
\text { ozone formation }\end{array}$ & $\begin{array}{l}\text { Photochemical ozone } \\
\text { creation potential for } \\
\text { each emission to air }\end{array}$ & $\begin{array}{l}\mathrm{kg} \text { ethylene } \\
\text { equivalents }\end{array}$ \\
\hline Acidification & $\begin{array}{l}\text { Emissions of } \\
\text { acidifying substances } \\
\text { to air }\end{array}$ & $\begin{array}{l}\text { RAINS } 10 \\
\text { model, developed at } \\
\text { IIASA, describing the } \\
\text { fate and deposition } \\
\text { of acidifying } \\
\text { substances }\end{array}$ & $\begin{array}{l}\text { Deposition/ } \\
\text { Acidification } \\
\text { critical load }\end{array}$ & $\begin{array}{l}\text { Acidification potential } \\
\text { (AP) for each emission } \\
\text { to air }\end{array}$ & $\begin{array}{l}\mathrm{kg} \mathrm{SO}_{2} \\
\text { equivalents }\end{array}$ \\
\hline Nutrification & $\begin{array}{l}\text { Emissions of nutrients } \\
\text { to air, water and soil }\end{array}$ & $\begin{array}{l}\text { Stoichiometric proce- } \\
\text { dures, which identify } \\
\text { the equivalence } \\
\text { between } \mathrm{N} \text { and } \mathrm{P} \text { for } \\
\text { both terrestrial and } \\
\text { aquatic systems }\end{array}$ & $\begin{array}{l}\text { Deposition } / \mathrm{N} / \mathrm{P} \\
\text { equivalents in } \\
\text { biomass }\end{array}$ & $\begin{array}{l}\text { Nutrification potential } \\
\text { (NP) for each emission } \\
\text { to air, water and soil }\end{array}$ & $\begin{array}{l}\mathrm{kg} \mathrm{PO}_{4} \\
\text { equivalents }\end{array}$ \\
\hline
\end{tabular}




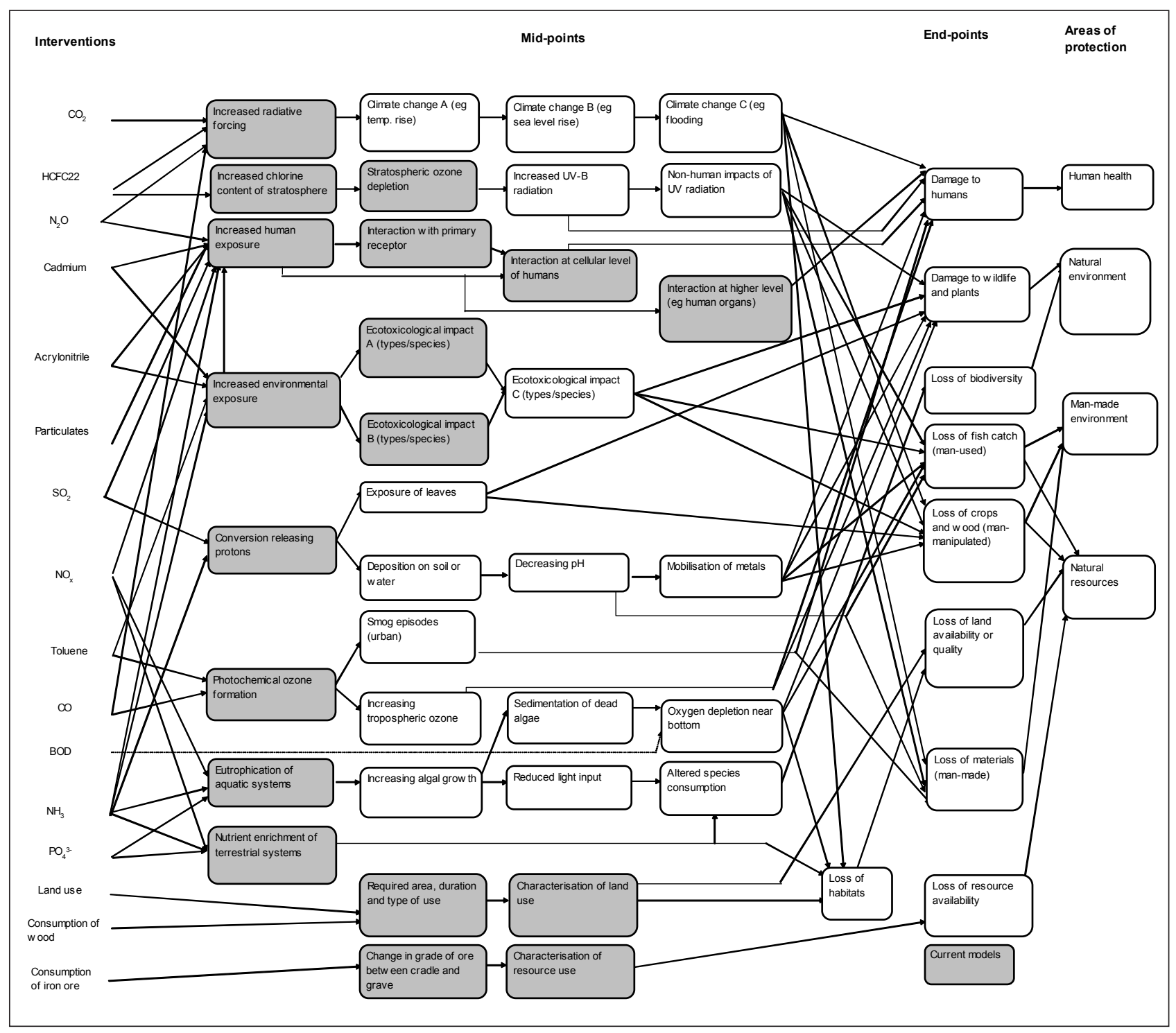

Figure 1

Causal relationships between interventions, mid-points and end-points (Guinee, 2000)

These scores are, however, not easy to compare since they are usually presented in different units. A normalisation step can therefore be added to identify the size of the contribution to an impact category in terms of the size of the total problem. An additional step is sometimes included, where the normalised values are weighted in order of importance (usually determined subjectively) (Guinee, 2000).

The causal relationships in an environmental mechanism are shown in Fig. 1.

From Table 1 and Fig. 1 it can be seen that, at this point in the development of the LCA methodology, most models have been developed for characterisation of the environmental impacts at mid-point level only. There are, however, still several mid-points that have not been described by means of models. Furthermore, the quantitative links between mid- and end-points (called damage functions) are only in the beginning stages of development.

A lot of work has been done since 1992 on models and category indicators that calculate and indicate effects on end-points. The most comprehensive and recent work in this area is the Ecoindicator 99 by Goedkoop and Spriesma (1999).
In general, definition of an indicator closer to the environmental interventions will result in more transparent modelling, but will render the indicator less environmentally relevant. In contrast, definition closer to the end-points will make the indicator more environmentally relevant, but will render it less transparent in its relationship to environmental interventions. Definition of an indicator at the level of the end-points themselves implies maximum environmental relevance.

Choosing indicators at different levels, however, will require very close attention to the consistency of the impact framework as a whole, avoiding as much as possible any overlap between categories, or missing types of impact. This can be difficult if some indicators are defined at end-point level and others at levels earlier in the mechanism.

The environmental themes (impact category) approach at midpoint level is currently considered to be best practice (Guinee, 2000).

In considering how to incorporate salinity into the LCA methodology therefore, one must take into account the current LCA best practice, but also the way in which LCA best practice is developing. 
TABLE 2

Requirements for defining new impact categories (Udo de Haes et al., 1999)

General starting point:

1. A framework shall be developed which is open to further scientific progress and further detailing of new information.

Starting points for total categories:

2. The categories shall together enable encompassing assessment of relevant impacts, which are known today.

3. The categories should have the least overlap possible (independence).

4. The total of the impact category should amount to a not too high number (practicality).

\section{Starting points for separate impact categories:}

5. The category indicator can be chosen anywhere in the environmental mechanism of an impact category, from environmental interventions to category end-points.

6. The category indicator should be modelled in a scientific and technically valid way in relation to the environmental interventions (i.e. using a distinct identifiable environmental mechanism and/or reproducible empirical observation).

7. The category indicator shall be environmentally relevant (i.e. it shall have sufficiently clear links to the category end-points).

8. It must be possible for characterisation factors to be multiplied by mass or other units indicating the magnitude of the environmental interventions.

Ultimately, it is envisioned that salinity damage functions will be developed, that link end-points to mid-points.

\section{Requirements for defining new impact categories}

A number of requirements for definition of new impact categories have been defined by SETAC. These are shown in Table 2 .

An important limitation set by ISO in defining new impact categories is that value choices are not allowed in comparative assertions. The SETAC-Europe working group may, however, deviate from this ISO requirement. The number of impact categories has to be limited by practicality. One possible way to split categories that are too heterogeneous and do not allow for scientifically valid aggregation is to use sub-categories (Udo de Haes et al., 1999).

\section{Salinity effects}

In order to determine whether the creation of a salinity impact category has merit and meets the requirements for new categories, it is prudent to define the terms "salinity" in the context of environmental LCA, and to review the effects of salinity.

In the Water Quality Guidelines for Aquatic Ecosystems (DWAF, 1996) salinity, described as total dissolved salts (TDS), is classified as a non-toxic inorganic constituent. Non-toxic inorganic constituent are in turn defined as ones which may cause toxic effects at extreme concentrations, but which are generally system variables in that their natural concentrations depend on localised geochemical, physical and hydrological processes.

A distinction is therefore made between toxic inorganic constituents (such as heavy metals) that are toxic at low concentrations (in the order of up to several mg/ $\ell$ (Van Vuuren et al., 1994)), and so-called non-toxic inorganic constituents, or common ions (such as sodium, calcium, magnesium, chloride, sulphate and bicarbonate) that only exhibit toxic and other effects at high (in the order of hundreds to thousands of $\mathrm{mg} / \ell$ ) concentrations that are above normal background levels (DWAF, 1996). In defining a salinity impact category in the context of LCAs, "salinity impacts" are therefore defined as those impacts caused by elevated (above natural background levels) common ion concentrations.

Sodium, calcium, magnesium, chloride, sulphate and bicarbonate ions make up the major fraction of the total ionic concentration in South African waters. Using Maucha diagrams, Day and King (1995) classify surface water in South Africa into four categories, based on proportional concentrations of dominant ions:

Category 1: Dominant ions are $\mathrm{Ca}^{2+}, \mathrm{Mg}^{2+}, \mathrm{HCO}_{3}^{-}\left(\mathrm{Na}^{+}\right.$is less than $25 \%$ of cations). These waters are "rock dominated", and are restricted to the regions of the high altitude basalt cap of Lesotho/KwaZulu-Natal and the dolomite and Pretoria Series of the Northern Province.

Category 2: Dominant ions are $\mathrm{Ca}^{2+}, \mathrm{Mg}^{2+}, \mathrm{HCO}_{3}^{-}\left(\mathrm{Na}^{+}\right.$is greater than $25 \%$ of cations). These waters are "rock dominated", mostly encircling Category 1 at lower altitudes. They also occur on Karoo and Waterberg sedimentary rocks and igneous rocks of the Basement Complex and the Bushveld Igneous Complex.

Category 3: Dominant ions are $\mathrm{Ca}^{2+}, \mathrm{Mg}^{2+}, \mathrm{HCO}_{3}^{-}, \mathrm{Na}^{+}, \mathrm{Cl}^{-}$(more or less co-dominant). These waters are widespread and not apparently associated with any particular geological formations.

Category 4: Dominant ions are $\mathrm{Na}^{+}$and $\mathrm{Cl}^{-}$. Dilute waters in Category 4 are rainfall dominated, and concentrated water is evaporation-rainfall dominated. They occur in the south-western Cape on Table Mountain Sandstones, in the western arid regions on Karoo sediments, and in coastal KwaZulu-Natal on a variety of substrata.

The categories defined show clear regional patterns, that are attributed to geological influences.

The $\mathrm{pH}$ of water does not affect the TDS concentration in water (at very high or very low levels of $\mathrm{pH}$ ). Changing the $\mathrm{pH}$ of water 
does, however, change the concentration of both $\mathrm{H}^{+}$and $\mathrm{OH}^{-}$, which in turn affects the ionic and osmotic balance of aquatic organisms. Relatively small changes in $\mathrm{pH}$ are not normally lethal, although sublethal effects may occur. Most often, lethal effects are related to the mobilisation of toxic substances (Dallas and Day, 1994). The $\mathrm{pH}$ values for natural waters in South Africa usually range between 6.5 and 8.0 (Dallas et al., 1998).

Elevated salt levels in South African surface waters (Dallas and Day, 1994) and groundwaters (Du Preez et al., 2000) have been widely reported and are of national concern.

\section{Effects on soil and plants}

Both the inherent permeability and hard-setting characteristics of a soil can be modified by irrigation with highly saline water. The sodium adsorption ratio (SAR) is an index of the potential of irrigation water to induce sodic soil conditions. The SAR is calculated as follows:

$$
S A R=\frac{N a^{+}}{\left[\left(C a^{2+}+M g^{2+}\right) / 2\right]^{0.5}}
$$

Ion concentrations in the above expression are expressed as $\mathrm{mmol} / \ell$. An increase in SAR will result in a decrease in the permeability of the soil, thereby increasing runoff and decreasing the amount of water available for plant growth, and hence lowering the crop yield. Data on the effects of SAR on crop yields and quality are available (Du Preez et al., 2000).

Irrigation of saline water induces soil salinity, which results in a reduction of crop yields once a threshold soil salinity, which is specific to each crop, is exceeded. A plant's tolerance to salt depends not only on the salinity, but also on many other factors such as soil, climate, plant variety and growth stage, agronomic and irrigation practices. Plant parts are also not affected equally; shoot growth is usually influenced more than root growth. The leaf-tostem ratio is also often affected.

Salinity in the root zone can adversely affect growth due to either a decrease of the osmotic potential (decreased water availability) caused by the high concentration of soluble ions and/or specific ion effects, which include toxicity of specific ions and/or unfavourable ratios of such ions. In addition, salinity disrupts nutrition by decreasing the activity of nutrient ions due to ionic strength, regardless of the substrate (Barnard et al., 1998).

Published data on the effects of elevated concentrations of dissolved salts, and individual ions on plants (including various crops, ornamental shrubs, trees and ground-covers) are available (Maas, 1990). These data are usually expressed as threshold concentrations at which no yield loss occurs, and concentrations at which different yield losses occur.

High salt levels in surface water may also cause a decrease in the abundance and diversity of riparian vegetation. This, in turn, may modify temperatures, sediment inputs, organic material sources. Very little information is available on South African species, however: some data are available on Australian species (WRC, 2000b).

Phytoplankton communities may change slightly with an increase in salinity, with less tolerant species giving way to more tolerant species (WRC, 2000b).

\section{Effects on animals and humans}

Saline water may detrimentally affect animal health by rendering the water unpalatable. Palatability is also influenced by the types of salt present. Magnesium sulphate is more harmful than sodium chloride or sodium sulphate. The main water quality constituents implicated in palatability effects are chloride, sulphate, magnesium, bicarbonates and calcium. Direct effects of unpalatability include the refusal to consume water, consumption below the physical requirement, or in extreme cases, over consumption. The main toxicological effects of high-salinity waters on animals include symptoms of diarrhoea and dehydration. Acute toxic effects related to specific ions are often indirectly due to the increased water intake and can elicit a toxic response at levels that are normally safe. Different species have different tolerances for saline water, and can adapt to a certain degree (DWAF, 1996).

Published data on salinity tolerances for livestock are available (Casey et al., 1998); however, very few data are available for wild animals. One report (WRC, 2000b) suggests that wildlife is not affected at salinity levels of up to $1200 \mathrm{mg} / \ell$ TDS.

Low concentrations of particularly calcium and magnesium salts have nutritional value, although water with an extremely low dissolved salts concentration is objectionable due to its flat, insipid taste. Human health effects related to dissolved salts are minimal at concentrations of below 2000 to $3000 \mathrm{mg} / \ell$. In contrast, high concentrations of salts impart an unpleasant taste to water and may also adversely affect the kidneys. Some of the human physiological effects that may be directly related to high salt concentrations include (DWAF, 1996):

- laxative effects, mainly from sodium sulphate and magnesium sulphate;

- adverse effects of sodium on certain cardiac patients and hypersensitive individuals;

- effects of sodium on women with toxaemia associated with pregnancy; and

- some effects on kidney function

Target water quality objectives are published for human health and taste effects for TDS, and for selected ions (DWAF, 1996).

\section{Effects on aquatic ecosystems}

Each species of aquatic organism is adapted to living in water of a certain quality, although some can tolerate wide differences in concentration of a wide variety of constituents, whereas others cannot (Dallas and Day, 1994). Changes in the dissolved salt concentration can have an effect on individual species, community structures and on microbial and ecological processes such as rates of metabolism and nutrient cycling (Dallas et al., 1998)

In a review done by Jooste et al. (2000), the lack of data on the sensitivity of freshwater plants and animals to salinity increases was highlighted. In general, however, it was concluded that for microbial communities, small changes in salinity have little effect. Many macrophytes are, however, sensitive and exhibit many sublethal responses. Invertebrates are most sensitive to increasing salinities. The most sensitive insects include stones, some mayflies, caddis-flies, dragon-flies and water-bugs. The most sensitive molluscs are pulmonate gastropods. Fish are generally tolerant to salinities in excess of $10000 \mathrm{mg} / \ell$ TDS; however, larval fish are more sensitive than adults, eggs are more tolerant than larvae. There is some evidence of low breeding success in water-birds where salinity levels are above $3000 \mathrm{mg} / \ell$. Freshwater turtles are most at risk.

Results on salinity tolerances of selected macro-invertebrates of the Sabie River in the Kruger National Park of South Africa tested by Palmer and Scherman (2000) linked mortality to increas- 


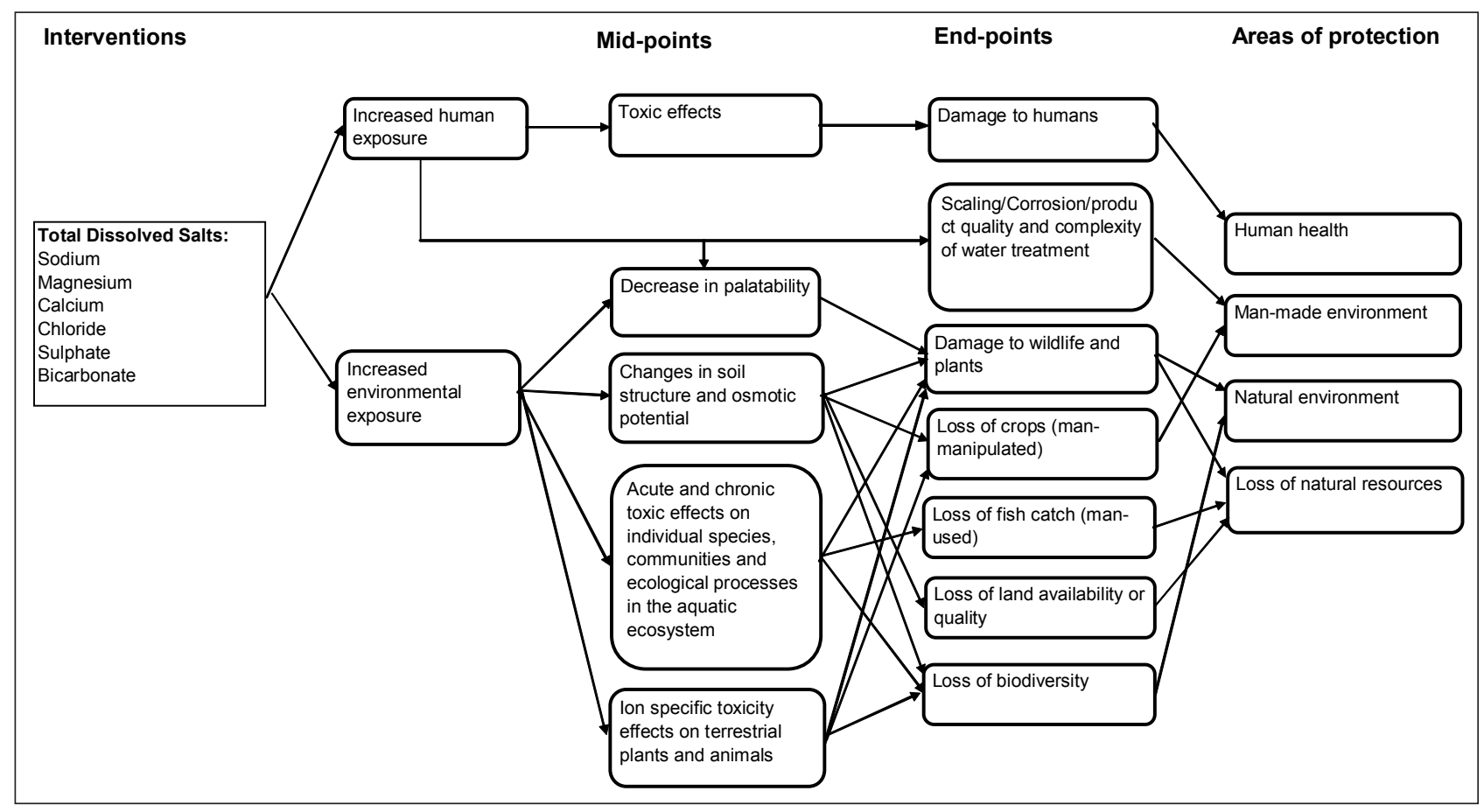

Figure 2

Causal relationships between interventions, mid-points and end-points for salinity

ing salinity and the nature of the salt used to elevate the salinity.

The South African Water Quality Guidelines for Aquatic Ecosystems (DWAF, 1996) state that the rate of change in salt concentration, and the duration of change appear to be more important than absolute changes in concentration. Guidelines are given in terms of concentration increase.

\section{Effects on man-made environment}

In conjunction with $\mathrm{pH}$ value, TDS values play a major role in the corrosion or scaling potential of water. Depending on the nature of the dominant cations and anions, the water will either have a tendency to scale (carbonates, sulphates, silica, calcium and magnesium) or corrode (chlorides and sulphates). High levels of dissolved salts can also indirectly interfere with the proper functioning of several industrial processes and may affect product quality. In addition, wastes discharged from industrial processes containing high salt levels will require more sophisticated and expensive treatment to remove the salts. Target water quality guidelines are published for different categories of industries (DWAF, 1996).

Several indices (such as the Langelier Saturation Index and calcium carbonate precipitation potential) can be used to indicate a water's tendency to scale or corrode; however, a detailed analysis of the water is required (WRC, 2000a).

Simplified causal relationships between interventions, midpoints and end-points for salinity are shown in Fig. 2.

It is evident that salinity as defined, has sufficiently clear links to category end-points. Furthermore, there are clear cause-effect relationships between the sources and the impacts.

\section{Methodology for a new salinity impact category}

Environmental fate and exposure models are currently available for characterising toxicity (human and eco-toxicity), including terres- trial vegetation (Table 1). These models relate continuous emission fluxes to environmental concentrations. The models can be used in LCA to relate discrete emission pulses to time-integrated environmental amounts. Substance-independent input data (such as daily water intake, geophysical data, etc), and substance-dependent data (dissociation constants, degradation rate, etc.) are used as inputs to calculate a predicted environmental concentration (PEC) in each compartment (air, water, soil, etc.) (Huijbregts, 1999). Weighted risk characterisation ratios ( $\mathrm{RCR}$, which are either unitless, in $\mathrm{kg}$ or in $\mathrm{m}^{3}$ ) are calculated for each environmental compartment as follows:

$$
\text { WeightedRCR } R_{i, x, e}=\frac{\left(P E C_{i, x, e, c / s}\right) W_{i, c / s}}{P N E C_{x, c}}
$$

where:

i denotes the impact category

$\chi$ denotes the substance

$\mathrm{c}$ denotes the environmental compartment

$\mathrm{s}$ denotes the scale

e denotes the initial release compartment

$\mathrm{W}_{\mathrm{i}, \mathrm{cs} s}$ are impact-specific weighting factors for compartments (c) or scales (s)

The predicted no effect concentrations (PNEC) are obtained from toxicological information. The equivalency factors used in the characterisation stage of LCAs are calculated as follows (Huijbregts, 1999):

$$
E Q_{x, e}=\frac{\text { WeightedRCR }}{\text { Weighted }\left(R C R_{x, c, e}\right)_{\text {reference }}}
$$

where:

Weighted $\left(\mathrm{RCR}_{\mathrm{x}, \mathrm{c}, \mathrm{e}}\right)_{\text {reference }}$ is the weighted risk characterisation ratio for a reference substance (usually 1,4- dichlorobenzene, for human and ecotoxicity). 
Life-cycle activities could occur at any location on earth. Global environmental fate and effect models have therefore been developed to estimate equivalency factors. These models are nestled, steady-state models in which the globe is taken as a closed system. Predicted environmental concentrations on a continental scale are estimated by assuming continuous emissions (usually $1000 \mathrm{~kg} / \mathrm{d}$ ) into each environmental compartment (air, freshwater, soil, etc) on a mathematically defined standard regional scale. The regionalscale model is nestled within a (mathematically defined) continental-scale model, which in turn is nestled within a global-scale model. The equivalency factors generated by these models are therefore relevant to the defined continent (usually western Europe), and are unavoidably dependent on how the regional and continental areas are mathematically defined (Huijbregts, 1999). The substance-independent data used to define the standard regional environment (such as the area of the regional system, the average temperature, the average wind speed, the residence time of water, the fraction of surface water consumed by humans, partitioning coefficients, and so on) are thus not necessarily relevant to South Africa. Equivalency factors may vary by several orders of magnitude, depending on how the standard environment is defined (Huijbregts, 2002).

Furthermore, the current characterisation models have been developed for neutral organic compounds. The assumptions made in these models are not always relevant for ionic compounds (Van Beelen, 1998), even though they are used to estimate equivalency factors for some metal ions. No equivalency factors are available for the common ions associated with salinity effects.

In terms of salinity effects, which are extremely relevant to South Africa, the following can be concluded regarding current characterisation models:

- Current (toxicity) characterisation models do include some metal ions, but do not include the common ions normally associated with salinity effects. It may be possible to use the existing models to account for toxic salinity (as defined above) effects; however, the validity of using the existing models for ionic species is questionable. Furthermore, existing characterisation models do not take all salinity impacts into account.

- Equivalency factors calculated using existing (toxicity) characterisation models are in all likelihood not relevant to South African conditions.

It has been shown that salinity, as defined, has sufficiently clear links to category end-points and that there are clear cause-effect relationships between the sources and the impacts. Salinity impacts, which include impacts other than toxic effects alone, are sufficiently different in nature from existing categories.

There is therefore a strong case for a separate salinity impact category, within the framework of environmental LCAs. Ultimately a nestled global fate and effect model should be developed, with emissions entering a mathematically defined "standard South African environment". This model should be able to calculate characterisation factors for all compounds (organic and inorganic) and should include a separate salinity impact category. As a starting point, it is recommended that a regional (using a "standard South African environment") environmental fate and effect model be developed that specifically accounts for salinity effects. Conceptually, the model could be used to estimate predicted environmental concentrations (either for TDS or for individual common ions) in the various environmental compartments based on a continuous release into various initial release compartments. It is envisaged that a salinity impact category will consist of the following subcategories:
- material damage;

- aesthetic effects;

- aquatic ecosystem effects; and

- terrestrial ecosystem effects, comprising separate effects on terrestrial plants and animals.

The total salinity potential (or equivalency factor) for the release of compound $\chi$ into an initial release compartment (irc), can be calculated by the general formula:

$$
\begin{aligned}
& T S P_{x, i r c}=\left(A E E P_{x, i r c}\right) W_{A E E}+\left(A e E P_{x, i r c}\right) W_{A e E}+\left(M d P_{x, i r c}\right) W_{M d E} \\
& +\left(T A E P_{x, i r c}\right) W_{T A E}+\left(T P E P_{x, i r c}\right) W_{T P E} \\
& \text { where: } \\
& \qquad \begin{array}{l}
\text { AEEP }=\text { aquatic ecosystem effects potential } \\
\text { AeEP }=\text { aesthetic effects potential } \\
\text { MdP }=\text { material damage potential } \\
\text { TAEP }=\text { terrestrial animal effects potential } \\
\text { TPEP }=\text { terrestrial plant effects potential. }
\end{array}
\end{aligned}
$$

Effect potentials are calculated as ratio-of-risk characterisation ratios for the compound and a reference substance as stated previously, but risk characterisation ratios are calculated as follows:

$$
R C R=\frac{P E C-P E C_{B}}{P N E C}
$$

where:

$$
\begin{aligned}
& \mathrm{PEC}= \text { predicted environmental concentration with a } \\
& \text { continuous emission of compound into the initial } \\
& \text { release compartments. } \\
& \text { PEC }_{\mathrm{B}=} \begin{array}{l}
\text { predicted environmental concentration without } \\
\text { emissions. }
\end{array}
\end{aligned}
$$

Weighting factors (W) are required in order to determine the relative importance (or value) of the salinity sub-impacts listed above. For example, the calculated value of the aesthetic effects potential may be larger than the calculated value of the aquatic ecosystem effects potential, which would imply that aesthetic impacts have more environmental "value" than aquatic ecosystem effects. Clearly, this would not be the case. By sub-categorising the salinity impact category, therefore, value judgements would have to be made regarding the relative weighting between sub-categories. This is beyond ISO, but not in conflict with ISO (Udo de Haes, 1999). The work done by the Water Research Commission on the economic cost effects of salinity (WRC, 2000) may be useful in calculating the weighting factors, based on valid scientific methods.

The total salinity impact category score used in LCA is then calculated as the product of the total salinity potential and the mass of component taken from the life-cycle inventory (LCI).

The terms "effects potentials" are used rather than "toxicity potentials", even though many of the salinity effects are indeed toxicological in nature. This is, however, done to distinguish toxicological effects that occur from compounds at low concentrations (such as heavy metals) from the effects that common ions have at high concentrations, as stated in the definition for salinity above.

Human toxic effects are initially excluded from the above conceptual methodology for defining a salinity impact category for the following reasons:

- Toxic effects in humans due to common ions occur only at very high concentrations. Humans will, by nature, avoid the intake 
of highly saline water or will treat the water to acceptable salinity levels before ingestion. This is not usually the case with aquatic and terrestrial ecosystems.

- Toxic effects by other ionic species are already accounted for in the calculation of human toxicity potentials using existing characterisation models.

\section{Conclusions and recommendations}

Elevated salt levels in surface waters and groundwaters in South Africa are a significant problem, of national concern. Existing characterisation models do not adequately account for the majority of salinity effects, and that these models are not suited to calculating equivalency factors for ionic compounds. Furthermore, the equivalency factors calculated by existing models apply to European conditions, and are not necessarily valid for South African conditions. The cause-effect relationships between sources and the effects are clear, and salinity impacts are sufficiently different in nature from existing categories to warrant a separate impact category.

A conceptual method is proposed for creating a new salinity impact category and for calculating salinity equivalency factors. The proposed method meets the SETAC requirements for creating new impact categories.

It is recommended that the model be developed and that, in the interim, the salinity equivalency factors be used in conjunction with published equivalency factors for conducting environmental life cycle assessments. The long-term goal should be to develop a global environmental fate-and-effect model, using a "standard South African environment" as initial release compartment. This model should be capable of calculating toxicity potentials for all compounds and should include a separate salinity impact category.

It is suggested that, as a starting point, target water quality objectives published in the South African Water Quality Guidelines (DWAF, 1996) be used as predicted no-effect concentrations. There is, however, a large degree of uncertainty related to the guideline values. Further research should be directed at gathering South African species-specific toxicological data. In addition, further research on the role of common ions in the mobility of toxic compounds should be investigated.

This paper is the first in what is anticipated to be a three-part series. The second paper will explore the theoretical foundations on which current models are based in more detail, and will present a conceptual fate-and-effect model for determining salinity potentials. The final paper will present the results of the fate-and-effect modelling.

\section{References}

BARNARD RO, RETHMAN NFG, ANNANDALE JC, MENTZ WH and JOVANOVIC NZ (1998) The Screening of Crop, Pasture and Wetland Species for Tolerance of Polluted Water Originating in Coal Mines. WRC Report No. 582/1/98. Water Research Commission, Pretoria.

CASEY NH, MEYER JA and COETZEE CB (1998) An Investigation into the Quality of Water for Livestock Production with the Emphasis on
Subterranean Water and the Development of a Water Quality Guideline Index System. WRC Report No. 644/1/98. Water Research Commission, Pretoria.

DALLAS HF and DAY JA (1994) The Effect of Water Quality Variables on Riverine Biotas. WRC Report No. 351/1/94. Water Research Commission, Pretoria.

DALLAS HF, DAY JA, MUSIBONO DE and DAY EG (1998) Water Quality for Aquatic Ecosystems: Tools for Evaluating Regional Guidelines. WRC Report No 626/1/98, Water Research Commission, Pretoria.

DAY JA and KING JM (1995) Geographical patterns, and their origins, in the dominance of major ions in South African rivers. S. Afr. J. Sci. 91 299-306.

DU PREEZ CC, STRYDOM MG, LE ROUX PAL, PRETORIUS JP, VAN RENSBURB LD and BENNIE ATP (2000) Effect of Water Quality on Irrigation Farming Along the Lower Vaal River: The Influence on Soils and Crops. WRC Report No 740/1/00, Water Research Commission, Pretoria.

DWAF (1996) South African Water Quality Guidelines. Vol 1 to 6. Department of Water Affairs and Forestry, Pretoria.

GOEDKOOP M and SPRIESMA R (2000) The Eco-indicator 99. A Damage Oriented Method for Life Cycle Assessment: Methodology Report ( $2^{\text {nd }}$ edn.). Pre Consultants. Amersfoort, Netherlands.

GUINEE JB (2000) Life Cycle Assessment: An Operational Guide to the ISO Standard. (Preliminary version). Centre of Environmental Science. Leiden Univ., Leiden, Netherlands.

HUIJBREGTS MA (1999) Priority Assessment of Toxic Substances in the Frame of LCA. Development and Application of the Multi-media Fate, Exposure and Effect model USES-LCA. Univ. of Amsterdam. Faculty of Environ. Sci., Amsterdam, Netherlands.

HUIJBREGTS MA (2002) Personal communication. Faculty of Environ. Sci., Univ. of Amsterdam.

JOOSTE S, MACKAY HM, SCHERMAN PA and MULLER WJ (2000) Feasibility of Using a Risk-Based Approach to Set Integrated Environmental Objectives for the Protection of Water Resources. WRC Report No. 914/1/00. Water Research Commission, Pretoria.

MAAS EV (1990) Crop Salt Tolerance. Agricultural Salinity Assessment and Management. American Society of Civil Engineers. New York.

PALMER CG and SCHERMAN PA (2000) Application of an Artificial Stream System to Investigate the Water Quality Tolerances of Indigenous, South African, Riverine Macro-Invertebrates. WRC Report No. 686/1/00. Water Research Commission, Pretoria.

UDO DE HAES HA, JOLLIET O, FINNVEDEN G, HAUSCHILD M, KREWITT W and MULLER-WENK R (1999) Best available practice regarding impact categories and category indicators in life cycle assessment. Int. J. LCA. 4 (2).

VAN BEELEN P (1998) Environmental Risk Evaluation of Difficult Substances in USES 2.0. National Institute of Public Health and the Environment (RIVM). Report 679102045. Bilthoven, Netherlands.

VAN VUUREN JHJ, DU PREEZ HH and DEACON AR (1994) Effect of Pollutants on the Physiology of Fish in the Olifants River (Eastern Transvaal). WRC Report No. 350/1/94. Water Research Commission, Pretoria.

WRC (2000a) The Economic Cost Effects of Salinity: Integrated Report. WRC Report No. TT 123/00. Water Research Commission, Pretoria.

WRC (2000b) The Economic Cost Effects of Salinity: Water Quality Analysis, Feeder Systems and Natural Environment. Volume VII. WRC Report No 634/6/00. Water Research Commission, Pretoria.

WENZEL H, HAUSCHILD M and ALTING L (1997) Environmental Assessment of Products. Chapman Hall. 